\title{
Some factors associated with the difference in nutritive value of artificially dried red clover and perennial ryegrass for sheep
}

\author{
BY G. MOSELEY AND J. R. JONES \\ Welsh Plant Breeding Station, Plas Gogerddan, \\ Aberystwyth, Dyfed $S Y_{23} 3 E B$
}

(Received 27 September 1978-Accepted I March 1979)

I. Three sheep fitted with duodenal re-entrant cannulas and three with large rumen fistulas were given red clover, perennial ryegrass and a $2: 1(\mathrm{w} / \mathrm{w})$ mixture of grass and clover in two Latin square arrangements. Measurements were made of voluntary intake, digestibility, flow of nutrients into the duodenum and the flow of Cr-EDTA marker through the reticulo-rumen.

2. Organic matter (OM) digestibility was similar for the three feeds but the voluntary intake decreased in the order mixture $>$ red clover $>$ perennial ryegrass. There was an increase in the rate of marker flow from the rumen and a decrease in retention time of the same order. Rumen volume did not change significantly.

3. There was a reduction in the mean particle size of rumen contents in the order perennial ryegrass $>$ clover $>$ mixture. The in vitro digestibility of particles decreased with size; the reduction being more rapid for clover than perennial ryegrass.

4. The proportion of ingested digestible OM appearing at the duodenum increased from $18 \cdot 4 \%$ to $26 \cdot 7 \%$ to $30.0 \%$ for perennial ryegrass, clover and the mixture respectively.

5. A higher proportion of digestible cellulose and hemicellulose disappeared over the stomach for the perennial ryegrass feed compared to the clover and the mixture but over $96 \%$ of water soluble carbohydrates and starch disappeared over the stomach for all three feeds.

6. The apparent digestibility of nitrogen was similar for all three feeds but the proportion of undigested feed $\mathrm{N}$ appearing at the duodenum was calculated to be greater by a factor of $\mathrm{I} \cdot 7 \mathrm{I}$ and 2.52 for clover and mixture feeds compared to grass.

7. It was concluded that the higher nutritive value of red clover compared to perennial ryegrass was due to an increased rate of flow of nutrients through the reticulo-rumen and an increase in the proportion of digestible $\mathrm{OM}$ digested post ruminally.

The value of red clover for ruminant feeding has received increasing attention in recent years, and various reports have indicated its potential in terms of increased animal production in both the grazed, i.e. fresh (Hodgson, 1975; Gibb \& Treacher, 1976) and dried (Miles et al. 1969; Patil et al. 1969; Moseley, 1974; Thompson, 1975) form.

In all these reports, animals feeding on red clover consumed more herbage and this alone must account for a large proportion of the improved production from both sheep and cattle. However, it was also reported that the efficiency of utilization of digested energy for weight gain was higher for sheep fed on red clover and red clover-supplemented grass diets than for grass or concentrate-supplemented grass diets (Moseley, 1974).

Similar improvements in the efficiency of utilization of feed by sheep has been observed with white clover diets (Grimes et al. 1967; Joyce \& Newth, I967; Rattray \& Joyce, I969; Ulyatt, I97I). These effects have been ascribed to a number of different causes including differences in the concentrations and proportions of volatile fatty acids produced in the rumen (MacLean et al. 1962; Johns et al. 1963; Grimes et al. 1967), differences in the retention time of organic matter in the rumen (Ulyatt, 1969) and differences in the amount of non-ammonia nitrogen digested in the small intestine (MacRae \& Ulyatt, 1974).

The present work was designed to further investigate the increases in voluntary intake and improvements in performance observed previously in animals fed on red clover diets. In view of the existing evidence from white clover feeding, the investigation concentrated on 
changes in rumen digestion and the flow of material from the stomach in order to establish some of the factors involved in intake regulation and the extent of any possible change in the site of digestion of major nutrients.

\section{MATERIALS AND METHODS}

\section{Feeds}

Perennial ryegrass (var. S. 23) was harvested from a I-year-old ley in July 1975 after spring grazing. The crop, which contained less than $10 \%$ unsown species, was artificially dried in a low temperature grass drier (Alvan Blanche, Chelworth, Malmesbury, Wiltshire) chopped to a staple length of $30 \mathrm{~mm}$ and compressed into paper sacks for storage. Red clover (var. Hungaropoly) sown in 1974 was harvested in late June 1975 and the crop, containing less than $15 \%$ unsown species, was dried and stored in the same manner.

\section{Animals}

The animals used were I8-month-old Clun Forest wether sheep weighing between 40 and $45 \mathrm{~kg}$. Three were prepared with re-entrant duodenal cannulas situated immediately beyond the pylorus and three with large $(60 \mathrm{~mm}$ aperture) rumen cannulas. All animals were maintained indoors on dry feed and during the experimental period they were allotted to metabolism crates, fitted with urine and faeces separators, and had free access to water.

\section{Experimental design}

Expt $\mathrm{I}$. The three re-entrant cannulated animals were allocated to a $3 \times 3$ Latin square with dietary treatments consisting of (I) dried grass, (2) dried red clover, (3) a 2 : I (w/w) mixture of grass and clover. Each treatment period consisted of an initial $14 \mathrm{~d}$ in which food was offered twice daily to an excess of approximately $15 \%$ of intake, and the voluntary intake was measured over the last $7 \mathrm{~d}$. This was followed by a $16 \mathrm{~d}$ period of interval feeding in which the feed offered was adjusted to $90 \%$ of the ad lib. intake and presented hourly in twenty-four equal amounts daily. Faeces were collected and intake recorded over the last Io $\mathrm{d}$ of this period and duodenal digesta was continuously sampled over the last $3 \mathrm{~d}$ by a modification of the automated procedure of Axford et al. (I97I).

Expt 2. The rumen cannulated animals were allocated to the same treatments as in Expt I. Faeces output and food intake were again recorded for the last $10 \mathrm{~d}$ of the second I6 d period. From day ir each animal received a priming dose and an intraruminal infusion of Cr-EDTA according to the method of Weston \& Hogan (1967). Samples were removed at regular $4 \mathrm{~h}$ intervals from four sites in the rumen by a suction device. When the concentration of $\mathrm{Cr}$ in the rumen had reached a plateau (day $\mathrm{I}_{5}$ ) the infusion was stopped and hourly samples were taken for the following I $2 \mathrm{~h}$. On day $\mathrm{I} 6$ a large bulk sample (approximately $3 \mathrm{l}$ ) of rumen contents was removed from several sites in the rumen using a large bore suction device. The bulk sample was thoroughly mixed and sub-samples obtained by plunging a $200 \mathrm{ml}$ vessel in the rumen contents. The remainder was then returned to the animal.

\section{Analyses}

Dry-matter content of food, faeces, duodenal digesta and rumen contents was measured by drying at $105^{\circ}$ for $24 \mathrm{~h}$. Organic matter (OM) content was measured by subtraction after ashing overnight at $450^{\circ}$. Fresh faeces, food and freeze dried duodenal digesta were analysed for nitrogen by the macro-Kjeldahl method. Cellulose and hemicellulose were determined on freeze-dried material by extraction with neutral detergent (Van Soest, 1966) and analysis 
Table I. Analysis of feeds $(\mathrm{g} / \mathrm{kg}$ dry matter $\mathrm{DM})$

\begin{tabular}{|c|c|c|c|c|c|c|}
\hline & $\begin{array}{c}\text { In vitro } \\
\text { DM } \\
\text { digestibility }\end{array}$ & Nitrogen & Cellulose & $\begin{array}{l}\text { Hemi- } \\
\text { cellulose }\end{array}$ & $\begin{array}{l}\text { Water } \\
\text { soluble } \\
\text { carbo- } \\
\text { hydrates }\end{array}$ & Starch \\
\hline $\begin{array}{l}\text { Perennial rye- } \\
\text { grass }\end{array}$ & 0.699 & 25.96 & 192.0 & 148.5 & $102 \cdot 0$ & I6.I \\
\hline Red clover & 0.719 & $25 \cdot 37$ & 146.0 & $93 \cdot 4$ & $95 \cdot 5$ & $33 \cdot I$ \\
\hline
\end{tabular}

of the residue by the acid-fractionation methods of Bailey (1967). Starch was determined by a modification of the method of Pucher et al. (1948) and water-soluble carbohydrates (WSC) by the method of Thomas (I977). The ammonia content of fresh duodenal digesta was estimated by the technique of Conway (I957). The calculation of flow-rate, rumen volume and marker retention time was carried out according to the method of Weston \& Hogan ( 1967 ) but $\mathrm{Cr}$ was analysed by the atomic absorption spectrophotometric method of Williams et al. (1962) using lanthanum chloride solution as a diluent following wet ashing of rumen contents with $15: 3: 2(\mathrm{v} / \mathrm{v})$ mixture of nitric acid, perchloric acid and sulphuric acid.

Triplicate $100 \mathrm{~g}$ samples of rumen contents from each bulk rumen sample were subjected to a particle size distribution analysis as described by Jones \& Moseley (1977). The fractions obtained for each feed were bulked and the in vitro digestibility measured by the technique of Tilley \& Terry (1963).

\section{RESULTS}

The in vitro dry matter (DM) digestibility and $\mathrm{N}$ content of both grass and red clover were similar but both cellulose and hemicellulose levels were higher in the perennial ryegrass than in the clover (Table I). The WSC was similar for both feeds but the starch content of clover was twice that of perennial ryegrass. Although they were not examined, pectin levels would be expected to increase the level of readily fermentable carbohydrates in the clover feed.

The digestibilities of $\mathrm{OM}$ of the three feeds were not significantly different but there was a $50 \%$ higher intake with clover than with perennial ryegrass and a further $17 \%$ higher intake with the mixture than with clover (Table 2). The total amount of OM appearing at the duodenum increased with intake and, the proportion of digestible $\mathrm{OM}$ that disappeared post-abomasally increased from 0.184 with perennial ryegrass to 0.267 with red clover and to 0.300 with the perennial ryegrass-clover mixture. Although the significance of the results relating to OM digestion were limited by the large LSD obtained with only two degrees of freedom, the differences between feeds were consistent for all animals and showeci a marked trend.

Of the OM components digested over the stomach, the amount of cellulose disappearing was similar for the perennial ryegrass and clover diets but was increased by $50 \%$ for the grass-clover mixture (Table 3). The proportion of digestible cellulose disappearing, however, decreased in the order perennial ryegrass $>$ clover $>$ the mixture. The over-all digestibility of cellulose in the gut was also higher for perennial ryegrass than clover, whereas the mixture was intermediate. Hemicellulose disappearance in the stomach (Table 3 ) was similar to cellulose but a smaller proportion of digestible hemicellulose was digested postabomasally. Of the soluble components of OM, both WSC and starch (Table 4) were almost completely digested in the stomach.

The amount of $\mathrm{N}$ appearing at the duodenum (Table 5) was closely related to the $\mathrm{N}$ intake 
Table 2. The digestion and flow of organic matter $(O M)$ through the gut of sheep fed on perennial ryegrass, red clover and perennial ryegrass-clover mixture

Intake $(\mathrm{g} / \mathrm{d})$

Faecal output $(\mathrm{g} / \mathrm{d})$

Duodenal flow $(\mathrm{g} / \mathrm{d})$

Disappearance over stomach $(\mathrm{g} / \mathrm{d})$

Disappearance post stomach $(\mathrm{g} / \mathrm{d})$

Digestible OM disappearing in

stomach $(\%)$

Digestible OM disappearing in intestines (\%)

Digestibility of OM

$\begin{array}{cc}\text { Grass } & \text { Clover } \\ 624 & 931 \\ 182 & 252 \\ 264 & 435 \\ 361 & 496 \\ 82 & 183 \\ 81.6 & 73.3 \\ 18.4 & 26.7 \\ 0.709 & 0.730\end{array}$

$\begin{array}{cc}\text { Mixture } & \text { SED } \\ 1093 & 70 \cdot 8 \\ 313 & 34 \cdot 8 \\ 550 & 56 \cdot 5 \\ 543 & 11 \cdot 4 \\ 237 & 30 \cdot 9 \\ 70 \cdot 0 & 3.56 \\ 30.0 & -\end{array}$

0.714

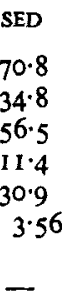

0.0146

Table 3. The digestion and flow of cellulose and hemicellulose through the gut of sheep fed on perennial ryegrass, red clover and perennial ryegrass-clover mixture

\begin{tabular}{|c|c|c|c|c|c|c|c|c|}
\hline & \multicolumn{4}{|c|}{ Cellulose } & \multicolumn{4}{|c|}{ Hemicellulose } \\
\hline & Grass & Clover & Mixture & SED & Grass & Clover & Mixture & SED \\
\hline Intake $(g / d)$ & $13 \mathrm{I} \cdot 7$ & I $46 \cdot 6$ & $207 \cdot 6$ & 13.52 & 103.6 & $93 \cdot \mathrm{I}$ & 156.5 & $12 \cdot 43$ \\
\hline Faecal output (g/d) & $3 I \cdot 3$ & $43 \cdot I$ & $55 \cdot \mathrm{I}$ & $5 \cdot 67$ & $28 \cdot 9$ & $28 \cdot 7$ & $53 \cdot 3$ & 5.54 \\
\hline Duodenal flow $(\mathrm{g} / \mathrm{d})$ & $37 \cdot 7$ & $59 \cdot 7$ & $83 \cdot 7$ & $9 \cdot 8 \mathrm{r}$ & $3 I \cdot I$ & 36.4 & 60.8 & 5.96 \\
\hline Disappearance in stomach $(\mathrm{g} / \mathrm{d})$ & 94.0 & 86.9 & $123 \cdot 9$ & $2 \cdot 69$ & $72 \cdot 5$ & $56 \cdot 7$ & $95 \cdot 7$ & $7 \cdot 47$ \\
\hline Disappearance in intestines $(\mathrm{g} / \mathrm{d})$ & $6 \cdot 4$ & $16 \cdot 6$ & $28 \cdot 4$ & $5 \cdot 27$ & $2 \cdot 2$ & $7 \cdot 7$ & $7 \cdot 5$ & $1 \cdot 90$ \\
\hline $\begin{array}{l}\text { Digestible intake disappearing in } \\
\text { stomach }(\%)\end{array}$ & $93 \cdot 6$ & $83 \cdot 8$ & $8 \mathrm{I} \cdot 7$ & $2 \cdot 99$ & $97 \cdot 4$ & 87.0 & $93 \cdot 2$ & 5.09 \\
\hline $\begin{array}{l}\text { Digestible intake disappearing in } \\
\text { intestines }(\%)\end{array}$ & $6 \cdot 4$ & $16 \cdot 2$ & $18 \cdot 3$ & - & $2 \cdot 6$ & $13 \cdot 0$ & $6 \cdot 8$ & 一 \\
\hline Digestibility over gut & 0.765 & 0.706 & 0.734 & 0.0123 & 0.719 & 0.695 & 0.659 & 0.0101 \\
\hline
\end{tabular}

Table 4. The digestion and flow of soluble carbohydrates and starch through the gut of sheep fed on perennial ryegrass, red clover and perennial ryegrass-clover mixture

\begin{tabular}{|c|c|c|c|c|c|c|c|c|}
\hline & \multicolumn{4}{|c|}{ Water soluble carbohydrates } & \multicolumn{4}{|c|}{ Starch } \\
\hline & Grass & Clover & Mixture & SED & Grass & Clover & Mixture & SED \\
\hline Intake $(g / d)$ & $69 \cdot 6$ & $97 \cdot 8$ & $120 \cdot 2$ & 774 & II 0 & $34 \cdot I$ & $26 \cdot 2$ & $2 \cdot 22$ \\
\hline Faecal output $(g / d)$ & $\mathrm{I} \cdot \mathrm{I}$ & $\mathrm{I} \cdot \mathrm{O}$ & $1 \cdot 8$ & & 0.2 & 0.6 & 0.8 & 0.16 \\
\hline Duodenal flow $(\mathrm{g} / \mathrm{d})$ & 3.0 & $4 \cdot 7$ & $6 \cdot 6$ & $1 \cdot 20$ & $0 \cdot 7$ & 0.9 & $\mathrm{I} \cdot 5$ & 0.33 \\
\hline Disappearance in stomach $(\mathrm{g} / \mathrm{d})$ & $66 \cdot 9$ & $93 \cdot \mathrm{I}$ & II 3.6 & 7.04 & 10.3 & $33 \cdot 2$ & $24 \cdot 7$ & $\mathrm{I} \cdot 98$ \\
\hline Disappearance in intestines $(\mathrm{g} / \mathrm{d})$ & $1 \cdot 9$ & $3 \cdot 7$ & $4 \cdot 8$ & 0.67 & 0.5 & 0.3 & 0.7 & $0.2 \mathrm{I}$ \\
\hline $\begin{array}{l}\text { Digestible intake disappearing in } \\
\text { stomach }(\%)\end{array}$ & $97 \cdot 2$ & $96 \cdot 2$ & $96 \cdot 3$ & 0.46 & $96 \cdot 0$ & $99 \cdot 2$ & $97 \cdot 2$ & $1 \cdot 57$ \\
\hline $\begin{array}{l}\text { Digestible intake disappearing in } \\
\text { intestines }(\%)\end{array}$ & 2.8 & $3 \cdot 8$ & 3.7 & - & $4 \cdot 0$ & 0.8 & $2 \cdot 8$ & - \\
\hline Digestibility & 0.984 & 0.990 & 0.985 & 0.010 & 0.984 & 0.982 & 0.972 & 0.055 \\
\hline
\end{tabular}

and, although the differences were not significant there appeared to be net losses of $\mathrm{N}$ in the stomach for perennial ryegrass and, to a smaller extent, for clover, but a net gain of $\mathrm{N}$ for the mixture. The over-all digestibility of $\mathrm{N}$ was similar for all three feeds but the amount disappearing post-abomasally was $60 \%$ higher with clover than with perennial ryegrass and I $5 \%$ higher with the mixture than with perennial ryegrass. 
Table 5. The digestion and flow of nitrogen through the gut of sheep fed on perennial ryegrass, red clover and perennial ryegrass-clover mixture

$\begin{array}{lcccc} & \text { Grass } & \text { Clover } & \text { Mixture } & \text { SED } \\ \text { Intake }(\mathrm{g} / \mathrm{d}) & \mathrm{I} \cdot 79 & 26 \cdot 12 & 30 \cdot 74 & \mathrm{I} \cdot 897 \\ \text { Faecal flow }(\mathrm{g} / \mathrm{d}) & 5.44 & 8.56 & 9 \cdot 28 & 0.982 \\ \text { Duodenal output }(\mathrm{g} / \mathrm{d}) & 15.72 & 25.14 & 31 \cdot 38 & \mathbf{2 . 5 9 8} \\ \text { Disappearance in stomach }(\mathrm{g} / \mathrm{d}) & 2.07 & 0.98 & -0.64 & 0.962 \\ \text { Disappearance in intestines }(\mathrm{g} / \mathrm{d}) & 10.28 & 16.57 & 22.09 & 0.828 \\ \text { Digestibility } & 0.696 & 0.673 & 0.698 & 0.1404\end{array}$

Table 6. The passage of fluid through the rumen of sheep fed on perennial ryegrass, red clover and perennial ryegrass-clover mixture

Dry matter intake $(\mathrm{g} / \mathrm{d})$

Rate of outflow of fluid (1/d)

Retention time for marker (h)

Volume of fluid in rumen (l)

$\begin{array}{rrrl}\text { Grass } & \text { Clover } & \text { Mixture } & \text { SED } \\ 1027 & 1045 & 1306 & 85 \\ 10.13 & 12.63 & 13.60 & 0.69 \\ 12 \cdot 14 & 9 \cdot 81 & 10.20 & 0.18 \\ 5.12 & 5.15 & 5.77 & 0.21\end{array}$

Table 7. The size distribution of particles in the rumen contents of sheep fed on perennial ryegrass, red clover and perennial ryegrass-clover mixture

\begin{tabular}{cccc} 
Sieve mesh & \multicolumn{3}{c}{$\begin{array}{c}\text { Accumulated \% } \\
\text { total of dry matter retained under sieve }\end{array}$} \\
\cline { 2 - 4 } size $(\mu \mathrm{m})$ & Grass & Clover & Mixture \\
4000 & 86.7 & $88 \cdot 5$ & 89.7 \\
2000 & 75.7 & 83.9 & 82.8 \\
1200 & 65.9 & 74.3 & 75.4 \\
600 & 54.4 & 62.4 & 64.2 \\
425 & 44.7 & $52 \cdot 1$ & 57.6 \\
300 & 34.6 & 36.7 & 46.7 \\
150 & 13.9 & 19.6 & 27.3
\end{tabular}

The DM intakes of the rumen-fistulated animals for perennial ryegrass and clover (Table 6) were not significantly different but the intake for the grass-clover mixture was approximately $30 \%$ higher. The rate of passage of fluid from the rumen increased significantly in animals fed on clover and perennial ryegrass-clover feeds compared to the ryegrass feed and this was reflected in the significantly lower retention time for the marker in the rumen. There was little change in rumen fluid volume between feeds although the grass-clover feed was slightly higher. The results of the particle size separation given in Table 7 show the total amount of DM collected which passed through the relevant sieve mesh, i.e. accumulative percent DM undersize each sieve. It may be seen that there was an increasing proportion of smaller particle size material in the rumen in the order perennial ryegrass $<$ clover $<$ mixture.

\section{DISCUSSION}

The nutritional superiority of red clover over perennial ryegrass for ruminant feeding reported by a number of authors has been associated with improvements in voluntary intake and live weight gain (e.g. Miles et al. 1969; Moseley, 1974; Thompson, 1975). Of the possible factors contributing to this improvement, probably the most important is the higher 
voluntary intake which was repeated in the present work, both as a single feed and as a mixture with perennial ryegrass.

Differences in the voluntary intake between forages have been correlated with many factors, including the physical and chemical composition of the forage and physiological changes within the animal (Raymond, 1969). Although no composite picture has yet emerged to explain how these differences arise, the conclusions of Campling (1970), that the voluntary intake of certain roughage diets is limited by the capacity of the reticulorumen and the extent of delay of food in this organ, must form the basis of any explanation.

Ingested forage undergoes a process of mechanical disintegration and microbial digestion in the mouth and rumen, and may leave the reticulo-rumen either by absorption and elution of soluble metabolites and nutrients or by the passage of particulate undigested material through the reticulo-omasal orifice to the hind gut. Thus, in order to improve the intake of forage, the rate of breakdown and removal of OM from the rumen must be increased either by an increase in the rate of microbial digestion and/or by an increase in the rate of passage of undigested food material to the hind gut.

A number of workers (e.g. Thornton \& Minson, 1972; Ulyatt, 197I) have shown that increasing intake of forage has been accompanied by a lower retention time in the rumen and an increased rate of flow from the rumen.

In the present study the retention times for red clover and perennial ryegrass-red clover mixture were $20 \%$ and $16 \%$ lower than perennial ryegrass, while the flow of fluid from the rumen was increased by $25 \%$ and $34 \%$ respectively. This finding agrees with published comparisons between legumes and grasses of temperate (Ulyatt, I969) and tropical (Thornton \& Minson, 1973) species. Furthermore, in Expt 2 the rate of flow of OM into the duodenum increased by $65 \%$ and $108 \%$ for red clover and perennial ryegrass-red clover mixture compared to the perennial ryegrass (Table 2). This shows that whereas the $\mathrm{OM}$ intake of red clover and perennial ryegrass-red clover mixture increased by $49 \%$ and $75 \%$ compared to perennial ryegrass, the disappearance of OM in the stomachs increased by only $38 \%$ and $50 \%$ respectively, while that disappearing post-abomasally increased by $124 \%$ and $190 \%$. Thus, although the total amount of OM disappearing in the stomach increased with intake, the disappearance per unit intake was lower. Consequently a higher proportion of undigested particulate material passed out of the rumen to the hind gut.

The bulk rumen samples which were subjected to particle size analysis were obtained from sheep which were on an hourly feeding regimen and, therefore, in a steady state with respect to the digestion of food in the rumen. It may be seen from the particle size distributions (Table 7) that the clover diets had a greater proportion of small particles in the rumen compared to the perennial ryegrass. This might suggest that the clover diets were more rapidly broken down to a smaller particle size and/or that a greater proportion of the large particulate material of the clover diets disappeared from the rumen by passage through the reticulo-omasal orifice.

The conclusion of Balch \& Campling (1962), that the most important factor regulating the movement of forage out of the rumen was its rate of breakdown to sufficiently small particles was supported by the work of Troelson \& Bigsby (I964) and Troelson (1967) who observed a direct relationship between the voluntary intake of hay by sheep and its rate of breakdown by artificial mastication to finer particles. Examination of this theory by Troelson \& Campbell (I968) showed that as voluntary intake increased, the degree of fineness of particles appearing in the omasum became greater. Furthermore, they showed that the relative size of omasal particles was greater in sheep fed alfalfa (Medicago media) than in sheep fed grass hay and suggested that this difference was associated with the variation in shape of alfalfa and grass particles passing to the omasum, and that this reflected the structure and composition of cell wall material. 
Table 8. The in vitro digestibility of particles separated from the rumen contents of sheep fed on perennial ryegrass, red clover and perennial ryegrass-clover mixture

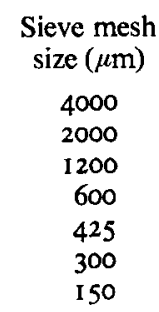

\begin{tabular}{llc}
\multicolumn{3}{c}{ In vitro digestibility } \\
Grass & Clover & Mixture \\
0.383 & 0.330 & 0.344 \\
0.349 & 0.303 & 0.337 \\
0.300 & 0.275 & 0.307 \\
0.241 & 0.251 & 0.248 \\
0.208 & 0.120 & 0.142 \\
0.167 & 0.110 & 0.163 \\
0.116 & 0.117 & 0.119
\end{tabular}

The in vitro digestibility values (Table 8 ) showed that the potential digestibility of the particles decreased with size; the clover feeds attaining very low levels of between 0. I I and 0.12 at the smallest particle size. This material would be virtually indigestible in the gut yet the proportion of post abomasal digestion increased with the clover feeds. It therefore seems probable that a greater proportion of the larger, more digestible particles of clover did pass through the reticulo-omasal orifice to the hind gut. This would be consistent with the results of Troelson \& Campbell (I968) which showed that the threshold size at which particulate material passed through the reticulo-omasal orifice was greater for the legume than for the grass. It would therefore appear that the higher voluntary intake characteristics of red clover were associated with a more rapid reduction in the size of particles and the passage of larger particulate material out of the rumen. Although the values for red clover and perennial ryegrass-clover mixture feeds were not significantly different there did appear to be an improvement in the rate of passage of $O M$ through the rumen with the mixture. A similar synergistic effect of perennial ryegrass-clover mixture was observed previously (Moseley, 1974) when the digestibility and intake of the mixture was improved above the levels anticipated from an arithmetical addition of the components. Although this is not readily explained, it is possible that the presence of clover in the perennial ryegrass feed may modify the rumen environment leading to a more efficient digestion and flow of nutrients through the stomach.

The values in Table 2 show that there was a change in the proportions of $\mathrm{OM}$ digested in the stomach and hind gut. The OM disappearance in the stomach $(\mathrm{g} / \mathrm{kg} \mathrm{OM}$ intake) was 578,533 and 497 for the perennial ryegrass, red clover and perennial ryegrass-clover feeds respectively, while the corresponding values for disappearance post abomasally were 131 , 196 and 217 . Of the components of OM disappearing over the gut, virtually all the watersoluble carbohydrates and starch disappeared in the stomach for all diets. A higher pectin contribution from clover would also increase the total amount of readily fermentable carbohydrates disappearing in the stomach for clover feeds. However, proportionally less of the cellulose and hemicellulose of the clover diets compared to the perennial ryegrass diet were digested in the rumen and, the post-ruminal fermentation of digestible cellulose and hemicellulose combined increased by $9.6 \%$ and $9.2 \%$ for the clover and perennial ryegrass-clover diets compared to perennial ryegrass. This increase in the proportion of digestible fibre disappearing post-ruminally is consistent with the rapid passage of more undigested food particles out of the rumen in sheep fed on clover feeds. The results also agree with those published by Hogan (1973), Beever et al. (I97I), MacRae \& Armstrong (1969), Topps et al. (1968) and Bruce et al. (I966), whose estimates for the proportion of digestible $O M$ disappearing in the large intestine for dried forages range from 0.08 to 0.16 . It would therefore appear from the increase in post ruminal disappearance of cellulose and 
Table 9. Calculated partition of nitrogen at the duodenum in sheep fed on perennial ryegrass, red clover and perennial ryegrass-clover mixture

\begin{tabular}{|c|c|c|c|}
\hline & Grass & Clover & Mixture \\
\hline Total $\mathrm{N}$ at duodenum $(\mathrm{g} / \mathrm{d})$ & $15 \cdot 72$ & 25.14 & $31 \cdot 38$ \\
\hline Non-ammonia $\mathrm{N}$ at duodenum $(\mathrm{g} / \mathrm{d})$ & 1498 & 23.80 & 29.86 \\
\hline Microbial $\mathrm{N}$ at duodenum $(\mathrm{g} / \mathrm{d})$ & $\begin{array}{c}10 \cdot 14 \\
(5 \cdot 59-13 \cdot 00)^{*}\end{array}$ & $\begin{array}{c}13.93 \\
(7.69-17.90)\end{array}$ & $\begin{array}{c}15 \cdot 25 \\
(8 \cdot 42-19 \cdot 55)\end{array}$ \\
\hline Undigested feed $\mathrm{N}$ at duodenum $(\mathrm{g} / \mathrm{d})$ & $\begin{array}{c}4 \cdot 84 \\
(\mathrm{I} \cdot 98-9 \cdot 39)\end{array}$ & $\begin{array}{c}9 \cdot 87 \\
(5 \cdot 90-16 \cdot 10)\end{array}$ & $\begin{array}{c}14 \cdot 6 \mathrm{r} \\
(10 \cdot 30-21 \cdot 60)\end{array}$ \\
\hline$\frac{\text { Undigested feed } \mathrm{N}}{\text { Total }}$ & $\begin{array}{c}0.323 \\
(0.134-0.630)\end{array}$ & $\begin{array}{c}0.415 \\
(0.248-0.676)\end{array}$ & $\begin{array}{c}0.489 \\
(0.345-0.717)\end{array}$ \\
\hline
\end{tabular}

Assuming $28 / \mathrm{g}$ microbial $\mathrm{N} / \mathrm{kg}$ OM digested in stomach.

* Range.

hemicellulose that there was an increase in the proportion of OM digested in the large intestine but, from the results of the previously mentioned workers it is unlikely that this would exceed $16 \%$ of the total OM digested over the whole gut. There must therefore have been an increase in the proportion of OM disappearing in the small intestine for the clover feeds compared to the perennial ryegrass.

This conclusion differs from that of Ulyatt \& MacRae (1974) who found that there was no significant difference in the proportion of digestible OM disappearing over the small intestine for fresh white clover and perennial ryegrass. There are, however, differences between fresh and dried herbage particularly with regard to the availability of organic constituents in the rumen which could account for the conflicting findings. Nevertheless, these workers did suggest that at intakes higher than those studied, clover would show a proportional increase in the post ruminal digestion of $\mathrm{OM}$.

A large proportion of the $\mathrm{OM}$ arriving at the duodenum consisted of nitrogenous components (approximately $36 \%$ of dry $\mathrm{OM}$ as crude protein) which may be classified mainly as microbial protein, undigested food residues, ammonia and endogenous protein. Although the contribution of microbial $\mathrm{N}$ to non-ammonia $\mathrm{N}$ appearing at the duodenum was not measured, it is possible to estimate from published results (e.g. Hogan, 1973; Hume \& Purser, 1974; Walker et al. 1975) that, with dried forages of similar digestibility fed to sheep, approximately $28 \mathrm{~g}$ microbial $\mathrm{N}$ is produced per $\mathrm{kg}$ of $\mathrm{OM}$ digested in the rumen (range I 5.5-36.0). Extrapolation of the values (Table 9) using this factor would suggest that there was an increasing amount of undigested feed nitrogen entering the duodenum in the order perennial ryegrass < clover < perennial ryegrass-clover mixture. If this undigested feed fraction is expressed as a percentage of $\mathrm{N}$ intake, then it would also suggest that an increased proportion of the feed $\mathrm{N}$ became available for digestion at the proximal duodenum. The significance of an increased proportion of post-ruminal digestion of $\mathrm{OM}$, particularly of protein to the efficiency of utilization of food is well recognized (e.g. Blaxter \& Martin, 1962).

These findings give some indication of the reasons for the more rapid flow of material through the rumen with red clover feeds as opposed to perennial ryegrass and also show that there was a significant shift in the proportion of OM digested from the rumen to the hind gut. This change in the site of OM digestion may offer an explanation for the improved efficiency of utilization of digested energy reported for red clover diets compared to perennial ryegrass and possibly also for similar improvements noted with white clover diets as compared to perennial ryegrass. The apparent enhancement of effects in the perennial ryegrassclover mixture was not readily explained with existing results and merits further examination. 


\section{REFERENCES}

Axford, R. F. E., Evans, R. A. \& Offer, N. W. (1971). Res. vet. Sci. 12, I 28.

Bailey, R. W. (1967). N.Z. Jl agric. Res. ıo, I 5.

Balch, C. C. \& Campling, R. C. (1962). Nutr. Abstr. 32, 669.

Beever, D. E., Thompson, D. J., Pfeffer, E. \& Armstrong, D. G. (I97I). Br. J. Nutr. 26, 123.

Blaxter, K. L. \& Martin, A. K. (1962). Br. J. Nutr. I6. 397.

Bruce, J., Goodall, S. D., Kay, R. N. B., Phillipson, A. T. \& Vowles, L. E. (1966). Proc. R. Soc. Ser. B. I66, 46.

Campling, R. C. (1970). In Physiology of Digestion and Metabolism in the Ruminant [A. T. Phillipson, editor]. Newcastle-upon-Tyne: Oriel Press.

Conway, E. J. (1957). Microdiffusion Analysis and Volumetric Error, 4th ed. London: Grosby, Lockwood \& Sons Ltd.

Gibb, M. J. \& Treacher, T. T. (1976). J. agric. Sci., Camb. 86, 355.

Grimes, R. C., Watkin, B. R. \& Gallagher, J. R. (1967). J. agric. Sci., Camb. 6r, 201.

Hodgson, J. (1975). J. Br. Grassld Soc. 30, 307.

Hogan, J. P. (1973). Aust. J. agric. Res. 24, 587.

Hume, I. D. \& Purser, D. B. (1974). Aust. J. agric. Res, 26, 199.

Johns, A. T., Ulyatt, M. J. \& Glenday, A. C. (1963). J. agric. Sci., Camb. 61, 20 I.

Jones, J. R. \& Moseley, G. (1977). Lab. Pract. 26, 687.

Joyce, J. P. \& Newth, R. P. (1967). Proc. N.Z. Soc. Anim. Prod. 27, 166.

MacLean, J. W., Thomson, G. G., Inversen, C. E., Jagusch, K. T. \& Lawson, D. M. (1962). Proc. N.Z. Grassld Ass, 24, 57.

MacRae, J. C. \& Armstrong, D. G. (1969). Br. J. Nutr. 23, 377.

MacRae, J. C. \& Ulyatt, M. J. (1974). J. agric. Sci., Camb. 82, 309.

Miles, D. G., Walters, R. J. K. \& Evans, E. M. (1969). Anim. Prod. I1, 19.

Moseley, G. (1974). Br. J. Nutr. 32, 3 I 7.

Patil, B. D., Jones, D. I. H. \& Hughes, R. (1969). Nature, Lond. 223, 1072.

Pucher, G. W., Leavenworth, C. S. \& Vickery, H. B. (1948). Analyt. Chem. 20, 850.

Rattray, P. V. \& Joyce, J. P. (1969). Proc. N.Z. Soc. Anim. Prod. 29, 102.

Raymond, W. F. (1969). Adv. Agron. 21, I.

Thomas, T. A. (1977). J. Sci. Fd Agric. 28, 639.

Thompson, D. J. (1975). J. Br. Grassld Soc. 30, 89.

Thornton, F. R. \& Minson, D. J. (1972). Aust. J. agric. Res. 23, 871.

Thornton, F. R. \& Minson, D. J. (I973). Aust. J. agric. Res. 24, 889.

Tilley, J. M. A. \& Terry, E. A. (1963). J. Br. Grassld Soc. 18, I04.

Topps, J. H., Kay, R. N. B. \& Goodall, E. D. (I968). Br. J. Nutr. 22, 26 I.

Troelson, J. E. (1967). System for estimating the nutritional quality of hay for domestic ruminants. Ph.D. thesis, University of Saskatchewan.

Troelson, E. \& Bigsby, F. W. (1964). J. Anim. Sci. 23, I I 39.

Troelson, J. E. \& Campbell, J. B. (1968). Anim. Prod. ro, 289.

Ulyatt, M. J. (1969). Proc. N.Z. Soc. Anim. Prod. 29, 114.

Ulyatt, M. J. (1971). N.Z. Jl. agric. Res. 14, 352.

Ulyatt, M. J. \& MacRae, J. C. (1974). J. agric. Sci., Camb. 82, 295.

Van Soest, P. J. (1966). J. ass. off. agric. Chem. 49, 546.

Walker, D. J., Egan, A. R., Nader, C. J., Ulyatt, M. J. \& Stover, G. B. (1975). Aust. J. agric. Res. $26,699$.

Weston, R. H. \& Hogan, J. P. (1967). Aust. J. agric. Res. 18, 789.

Williams, C. H., David, D. J. \& Iismaa, O. (1962). J. agric. Sci., Camb. 59, $3^{81 .}$ 